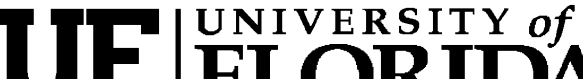 FLORIDA \\ IFAS Extension
}

ENH1068

\section{Nutrient Deficiencies in Production of Annual Floral Crops ${ }^{1}$}

James L. Gibson, Beth Bolles, Sheila Dunning, Theresa Friday, Dan Mullins, Carrie Stevenson, and Larry Williams ${ }^{2}$

Annual floral crops are profitable to produce because of their rapid growth rate and popularity among consumers. Fertility monitoring and management for annual floral crops requires a balancing of the plant's requirements. Growers must monitor and manage the root substrate $\mathrm{pH}$ and electrical conductivity (EC) and provide adequate but not excessive levels of essential elements. If fertilization and monitoring programs are not in put into practice, nutrient deficiencies can appear quickly within a crop and subsequently reduce profit by affecting marketability.

\section{Essential Nutrients}

Sixteen elements are considered to be essential for plant growth: carbon, hydrogen, oxygen, nitrogen, phosphorus, potassium, calcium, magnesium, sulfur, iron, manganese, copper, boron, zinc, molybdenum, and chlorine. These elements are essential because they have met these three criteria:
- The lack of the element makes it impossible for the plant to complete the vegetative or reproductive stage of life.

- The element cannot be replaced by supplying another element.

- The element must exert its effect directly on growth or metabolism.

\section{Macronutrient/ Micronutrient Translocation}

An important aspect in diagnosis of nutrient deficiencies is the location on the plant where the symptom is expressed. Understanding the translocation principle in floral plants will enable growers to correctly diagnose or pinpoint the macro or micronutrient disorder more efficiently.

1. This document is ENH1068, one of a series of the Environmental Horticulture Department, Florida Cooperative Extension Service, Institute of Food and Agricultural Sciences, University of Florida. Original publication date April 2007. Visit the EDIS Web Site at http://edis.ifas.ufl.edu.

2. Dr. James Gibson, Assistant Professor, Environmental Horticulture Department, West Florida Research and Education Center, Milton FL 32583; Beth

Bolles, UF/IFAS Extension Escambia County

3740 Stefani Road, Cantonment, FL 32533-7792; Sheila Dunning- UF/IFAS Extension Okaloosa County

5479 Old Bethel Road, Crestview, FL 32536-5512; Theresa Friday- UF/IFAS Extension Santa Rosa County

6051 Old Bagdad Highway, Milton, FL 32583-8944;Dan Mullins- UF/IFAS Extension Santa Rosa County

6051 Old Bagdad Highway, Milton, FL 32583-8944; Carrie Stevenson- UF/IFAS Extension Escambia County - Florida Yards and Neighborhoods Agent,

3740 Stefani Road, Cantonment, FL 32533-7792; andLarry Williams- UF/IFAS Extension Okaloosa County

5479 Old Bethel Road, Crestview, FL 32536-5512; UF/IFAS Gainesville, FL 32611

The Institute of Food and Agricultural Sciences (IFAS) is an Equal Opportunity Institution authorized to provide research, educational information and other services only to individuals and institutions that function with non-discrimination with respect to race, creed, color, religion, age, disability, sex, sexual orientation, marital status, national origin, political opinions or affiliations. U.S. Department of Agriculture, Cooperative Extension Service, University of Florida, IFAS, Florida A. \& M. University Cooperative Extension Program, and Boards of County Commissioners Cooperating. Larry Arrington, Dean 
Mobility of the nutrient or the ability of the element to translocate itself to another part of the plant has been determined for the essential elements (Table 1). Plants obtain nutrients from the substrate solution via root systems. Nutrients are incorporated into tissues, used for cellular growth, and utilized in photosynthesis or in the building blocks of plant tissue (See Table 1 for roles of the elements in plant growth).

Initially, nutrients are provided to plants from seed reserves, and as roots begin to develop, plants extract nutrients from the substrate. Once the nutrients become less available to the plant, the plant has to provide nutrients from older tissues so that the actively growing regions (shoot tips and axillary shoots) can continue to develop. Basically, the plant is attempting to promote life by supplying nutrients to the upper growth, which harbors the reproductive structures, enabling the continuation of the species.

Some elements are unable to be translocated. Differences between mineral translocation will be demonstrated below in a comparison example between nitrogen and calcium.

\section{Nitrogen Translocation}

Nitrogen is incorporated into organic molecules and is involved in the structures of all amino acids and proteins, and many enzymes. As levels of nitrogen become lower in the substrate, nitrogen is translocated from the lowest leaves to the actively growing regions of the shoot tip. Deficiency symptoms appear on the older leaves and a lighter green color is observed. As symptoms progress, the stem becomes weak, the new leaves become small, and the lower leaves drop. Death of the older leaves is an advanced nitrogen deficiency symptom.

\section{Calcium Translocation}

Calcium plays a major role in cell elongation and is an important component in cell walls; structurally it acts like cement between cells. Calcium moves up the plant via transpiration; if light levels are too low or there is high relative humidity, calcium deficiency can occur in young shoot tips. Calcium is an immobile nutrient, which means that it cannot be translocated from older tissue to the shoot tip.
Therefore new growth is severely reduced. Although calcium may be adequate in the lowermost leaves, levels in the growing tip region can be too low, causing poor leaf expansion followed by necrotic patches in the young leaves. Complete necrosis of the shoot is the advanced stage causing the inability of the reproductive structures to form. If flowers were present when calcium levels become devastatingly low in the substrate, bud abortion occurs.

Fertilizing with a commercial fertilizer should provide adequate levels of macro- and micronutrients. Unfortunately, several environmental and production factors can inhibit proper nutrition of annual floral crops.

pH. One factor that can influence the incidence of nutrient deficiencies in floral crops is the substrate $\mathrm{pH}$. The $\mathrm{pH}$ can range for most annual floral crops between 5.4 to 6.8 , but maintaining the $\mathrm{pH}$ between 5.6 to 6.2 is highly recommended. Poor uptake of nutrients, particularly boron, copper, iron, manganese, and zinc can occur if the $\mathrm{pH}$ of a substrate is above 6.5. Calcium and magnesium deficiencies are associated with low root substrate $\mathrm{pH}$.

Improperly Working Equipment. Weekly calibration of the injector is required. Malfunctioning equipment will cause multiple nutrient deficiencies, especially nitrogen, phosphorus, and potassium.

Improperly Working Equipment. Weekly calibration of the injector is required. Malfunctioning equipment will cause multiple nutrient deficiencies, especially nitrogen, phosphorus, and potassium.

Overwatering. Constant saturation of the substrate can lead to macro and micronutrient deficiencies. Overwatering reduces oxygen levels, which limits plant growth and slows water uptake by roots. Elements such as calcium are transported via waterflow, and deficiency symptoms can develop rapidly on new growth. Also the inactivity of root systems due to saturated conditions can lead to inefficient uptake of iron and/or phosphorus.

Low/High Soluble Salts. The term soluble salts refers to the total dissolved salts in the root substrate at any given time. Soluble salts are measured in terms of electrical conductivity (EC). When the EC content 
of the root substrate is too low, plant growth can become stunted and mineral deficiencies often are observed. Low salts usually result from too many clear water irrigations. Deficiencies among floral crops like lower leaf yellowing (nitrogen), lower leaf purpling (phosphorus), and lower leaf interveinal chlorosis (magnesium) are common when values are below $0.75 \mathrm{mS} / \mathrm{cm}$ (saturated media extraction [SME] or saturated paste method). High soluble salts can also reflect poor nutrition. High chlorides in irrigation water near coastal areas can damage roots and minimize uptake of nutrients like iron.

Mineral Antagonisms. When certain elements are provided in excess to plants, uptake of other nutrients may be hindered. One example of a mineral antagonism is the nitrogen-potassium interaction. For most floral crops a $1 \mathrm{~N}: 1 \mathrm{~K}$ ratio is recommended. Another type of antagonism is the potassium-calcium-magnesium interaction. Any one of these elements in excess can cause a decrease in the uptake of the others. The optimum ratio for floral crop growers is $4 \mathrm{~K}: 2 \mathrm{Ca}: 1 \mathrm{Mg}$. Furthermore, excess phosphorus can cause a decrease in uptake of zinc, iron, and copper. The iron: manganese ratio should be $1: 1$.

Temperature (Too Cold). Temperature can also play a role in the introduction of nutrient deficiencies. One classic example is the effect of low temperature $\left(<55^{\circ} \mathrm{F}\right)$ on the uptake of phosphorus in tomato. Purpling of the lower foliage is the common symptom. Geraniums also can express phosphorus deficiency when they are grown too cool in the spring.

Disease. Organisms like Pythium feed on the nutrients in roots causing an inefficient uptake of minerals. Iron deficiency (upper foliage interveinal chlorosis) can occur if root rot pathogens infect the root system.
Table 1. Essential nutrients which are important in bedding plant fertilization $^{\star * *}$.

Nitrogen: $\mathbf{N}$
Movement $^{\star *}$ : Mobile
Function: Involved in the synthesis of amino acids,
proteins, enzymes, and nucleic acids.
Deficiency Symptoms: Stunted, pale green to yellow,
weak stem, necrotic symptoms develop at a later stage.
Corrective Procedures: Applications include a liquid
substrate drench of calcium nitrate $\left(\mathrm{Ca}\left(\mathrm{NO}_{3}\right)_{2}\right)$ or
potassium nitrate $(\mathrm{KNO})$, or Excel $15-5-15^{2} \mathrm{Cal}-\mathrm{Mag}$ at
the rate of 300 to $400 \mathrm{ppm} \mathrm{N}$. Do not overapply; a single
application at 300 to 400 ppm $\mathrm{N}$ should return the lower
leaves a normal green color within 1 to 2 weeks.

\section{Phosphorus: $\mathbf{P}$}

Movement: Mobile

Function: Involved in energy transfer (ADP), nucleic acids, enzymes, and membrane structure.

Deficiency Symptoms: Slow and reduced growth, purple pigmentation of older leaves- accumulation of anthocyanin, foliage is a dark green, necrotic patches occur on the leaf margins at the advanced stage.

Corrective Procedures: Substrate applications of 20-10-20 at the rate of 200 ppm will supply 44 ppm of $P$. Also avoid cool night temperatures which can cause inactivity of root systems.

Potassium: K

Movement: Mobile

Function: Maintains the ionic balance and water status in plants, opening and closing of stomata, photosynthesis, sugar translocation, enzyme activity. Deficiency Symptoms: Slow growth, marginal chlorosis on older leaves, burned or scorched appearance at the advanced stage.

Corrective Procedures: Substrate applications include potassium nitrate $\left(\mathrm{KNO}_{3}\right)$ or $15-5-25$ at the rate of 300 to 400 ppm K.

Calcium: $\mathbf{C a}$

Movement: Immobile

Function: Constituent of cell walls, maintains cell wall integrity and membrane permeability, enhances pollen germination and growth, activates a number of enzymes for cell mitosis, division and elongation.

Deficiency Symptoms: Curled and distorted leaves, strap-like leaves on top, tips turning brown to black, vascular breakdown at the base of the plant, short roots with comb-like or "herring bone effect."

Corrective Procedures: Supplemental root substrate applications of calcium nitrate $\left(\mathrm{Ca}\left(\mathrm{NO}_{3}\right)_{2}\right)$ at $200 \mathrm{ppm}$ Ca. Visible improvements should be evident on the new growth within 2 to 3 weeks. Do not overapply. Also allow the substrate to dry before irrigating to prevent poor uptake of calcium. 
Table 1. Essential nutrients which are important in bedding plant fertilization ${ }^{* \star * *}$.

\section{Magnesium: $\mathbf{M g}$ \\ Movement: Moderately mobile \\ Function: A component of the chlorophyll molecule and involved in enzyme activation.}

Deficiency Symptoms: Interveinal chlorosis on older leaves, defoliation of the lower leaves at the advanced stage.

Corrective Procedures: Magnesium sulfate (Epsom Salts) application to the root substrate at the rate of 1 pound per 100 gallons of water will return the chlorotic tissue to the normal green color within 1 to 2 weeks. Do not mix with other fertilizers.

\section{Sulfur: S}

Movement: Mobility varies with species

Function: Constituent of two amino acids, cystine and thiamine, contributes to odor and taste of some plants.

Deficiency Symptoms: Slowed growth, general loss of green color, overall the plant appears to be a lighter green.

Corrective Procedures: Magnesium sulfate (Epsom Salts) application to the root substrate at the rate of 1 pound per 100 gallons of water will return the chlorotic tissue to the normal green color within 1 to 2 weeks. Do not mix with other fertilizers.

\section{Iron: Fe}

Movement: Immobile

Function: Necessary for the synthesis of chlorophyll, component of many enzyme and electron transport systems, component of protein ferredoxin.

Deficiency Symptoms: Interveinal chlorosis of younger leaves, young leaves become a bleached yellow at the advanced stage leading to necrotic burn on the tips and margins.

Corrective Procedures: Supplemental applications of iron chelate to the root substrate at the rate of $1 \mathrm{oz}$ per 15 gallons of water. Visible improvements should be evident within 2 weeks. Do not overapply. Another procedure is to apply a foliar spray of iron sulfate at a rate of $4 \mathrm{oz}$ per 100 gallons. This will provide $62 \mathrm{ppm}$ of iron. Do not overapply.

\section{Manganese: $\mathbf{M n}$}

Movement: Immobile

Function: Involved in chlorophyll synthesis, respiration, photosynthesis, and nitrogen assimilation.

Deficiency Symptoms: Leaf necrosis, either as spotting or interveinal scorch.

Corrective Procedures: Substrate drenches with 0.5 oz of manganese sulfate per 100 gallons of water. Do not overapply. Another corrective procedure is to apply a foliar spray of manganese sulfate at a rate of $2 \mathrm{oz}$ per 100 gallons.

This will provide $40 \mathrm{ppm}$ of manganese. Do not overapply.
Table 1. Essential nutrients which are important in bedding plant fertilization ${ }^{* * *}$.

\section{Zinc: Zn}

Movement: Immobile

Function: Component and an activator of enzymes Deficiency Symptoms: Upper new leaves will curl with rosette appearance, chlorosis in the interveinal areas, leaves will die and flowers will abscise.

Corrective Procedures: Substrate drenches with 0.5 oz of zinc sulfate per 100 gallons of water. Do not overapply. Another procedure is to apply a foliar spray of zinc sulfate at a rate of 2 oz per 100 gallons. This will provide $56 \mathrm{ppm}$ of zinc.

Do not overapply.

\section{Copper: $\mathrm{Cu}$}

Movement: Immobile

Function: Required for the activation of several enzymes, needed for chlorophyll synthesis, involved in the metabolism of carbohydrates and proteins.

Deficiency Symptoms: Reduced or stunted growth, distortion of the younger leaves and necrosis of the apical meristem.

Corrective Procedures: Substrate drenches with 0.5 oz. of copper sulfate per 100 gallons of water. This will provide $9.3 \mathrm{ppm}$ of copper. Do not overapply. Another procedure is to apply a foliar spray of tri-basic copper sulfate at a rate of $4 \mathrm{oz}$ per 100 gallons. This will provide $159 \mathrm{ppm}$ of copper. Do not overapply.

\section{Boron: B}

Movement: Immobile

Function: Associated with carbohydrate chemistry, pollen germination, and cellular activities (division, differentiation, maturation, respiration, and growth). Deficiency Symptoms: Stunting, possible death of the growing tips, leaf cupping, brittle young foliage, bud abortion, lack of fruit set and development, and roots are stunted with swollen stubby secondary roots.

Corrective Procedures: Substrate drenches with 0.75 oz of Borax per 100 gallons of water or $0.43 \mathrm{oz}$ of Solubor per 100 gallons of water. This will provide 6.25 ppm of boron.

*Adapted from: Identifying nutrient deficiencies of bedding plants. 2000. North Carolina State University. ${ }^{*}$ Carbon, hydrogen, oxygen, chlorine, and molybdenum are also essential nutrients; however deficiency symptoms are rare on most annual floral crops.

${ }^{* * *}$ Mobile nutrients can translocate from older tissue to younger tissue, immobile nutrients are fixed within the tissue and cannot translocate.

\section{Nutrient Deficiency Web Site}

In 2004, researchers at the West Florida Research and Education Center in Milton generated 
visual symptoms of nutrient deficiencies of $\mathrm{N}, \mathrm{P}, \mathrm{K}$, $\mathrm{Ca}, \mathrm{Mg}, \mathrm{S}, \mathrm{Fe}, \mathrm{Mn}, \mathrm{Cu}, \mathrm{Zn}$, or B in the chronological order in which they appeared from initial to advanced stages on Sunflower Big Smile' and Mexican sunflower. Seedlings were planted in 1.3-gallon plastic containers and fertilized with a complete nutrient solution, or this solution minus the element that was to be investigated. Plants were transferred to pots containing soilless substrate and photographed when initial foliar symptoms were expressed and later under advanced deficiency symptoms.

Visual diagnosis is a popular monitoring tool; however using a plant diagnostic lab to identify the source of nutritional problems is still the best way to ensure accurate diagnoses. Many nutritional, physiological, insect, and disease problems can mimic each other. Please visit the UF Commercial Floriculture Web site (http://hort.ifas.ufl.edu/floriculture/index.htm) to view deficiency symptoms of Mexican sunflowers and pot sunflowers.

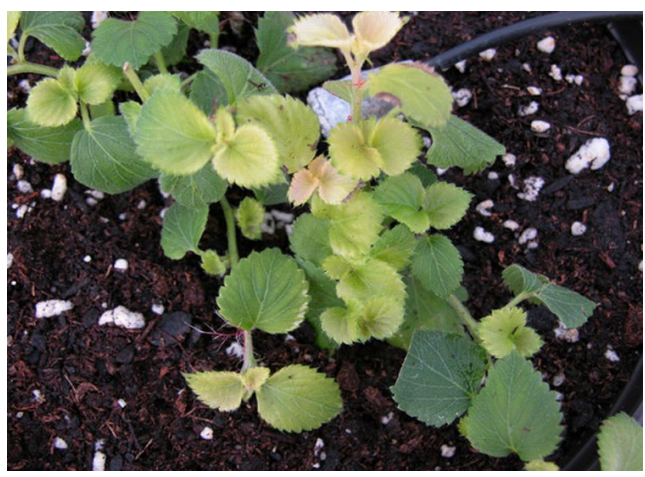

Figure 1. Iron deficiency in creeping chenille. High substrate $\mathrm{pH}$ due to excessively high irrigation water alkalinity made iron unavailable to the plant.

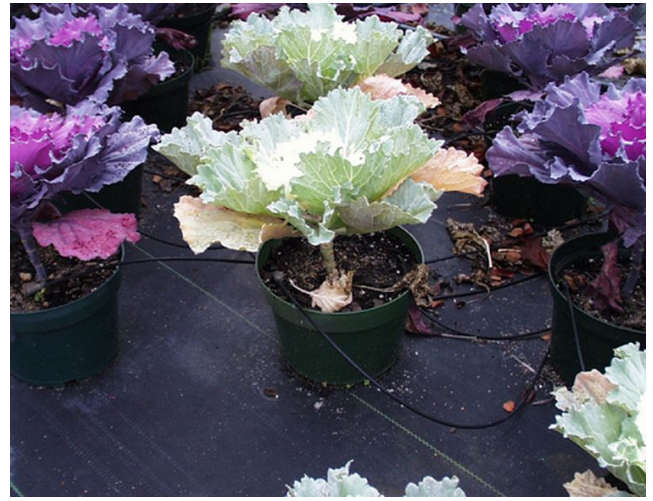

Figure 2. A broken injector has caused the substrate EC of this ornamental kale crop to decline rapidly.

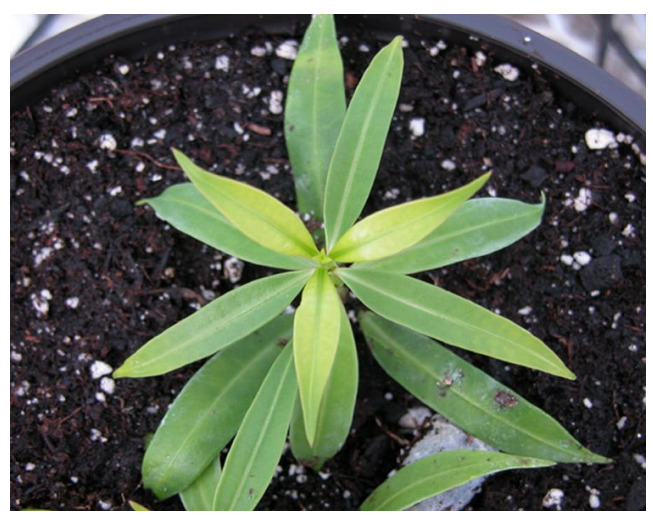

Figure 3. Iron deficiency in dwarf allamanda. Continued saturation of the root substrate has lead to inefficient root uptake of iron.

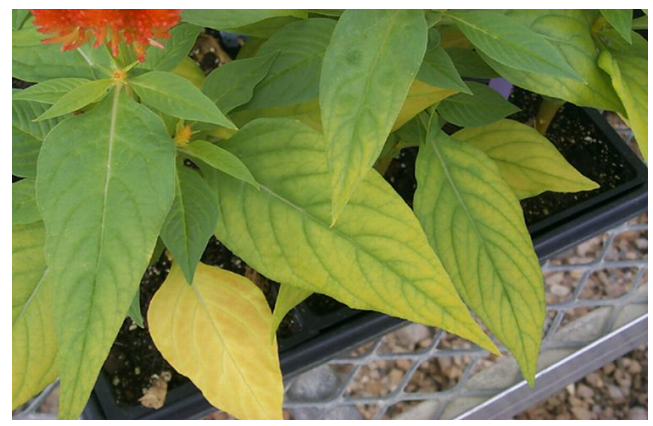

Figure 4. Symptoms of nitrogen (lower leaf yellowing) and magnesium (lower leaf interveinal chlorosis) on celosia. 


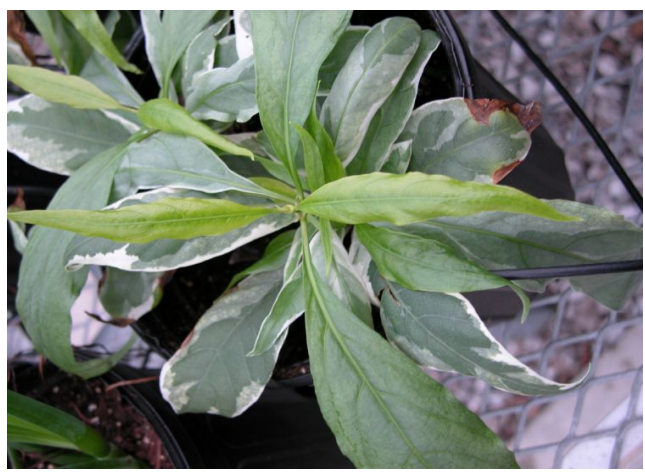

Figure 5. High magnesium in the irrigation water caused an antagonism with calcium, leading to strap-like growth (calcium deficiency) on this variegated firespike.

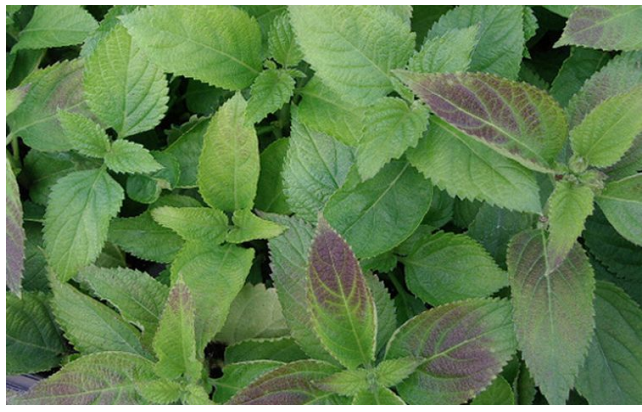

Figure 6. Cool temperatures during the hardening-off stage of these rooted lantana cuttings caused the foliage to express phosphorus deficiency symptoms (purpling).

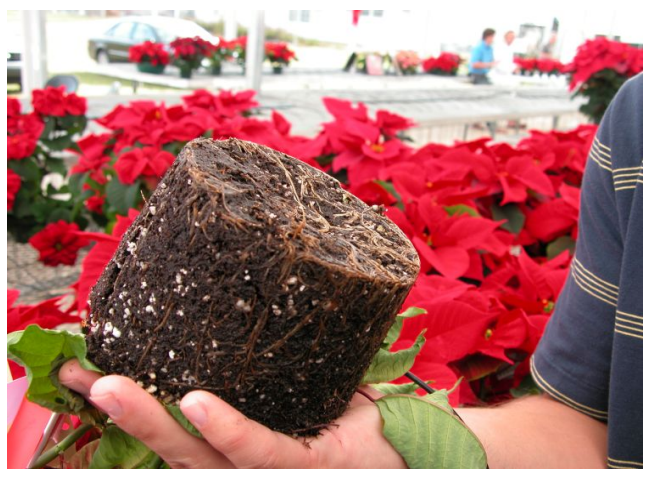

Figure 7. Insufficient uptake of nutrients can occur if the plant pathogen Pythium infects the root system. Root rots are often expressed above ground as iron deficiency.

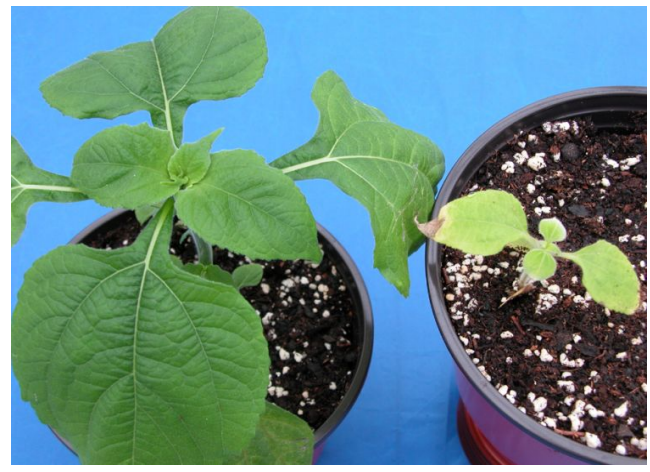

Figure 8. Nitrogen deficiency (right) compared to a healthy Mexican sunflower plant (left). Deficiency symptoms included stunted plants with lower leaf yellowing and leaf tip necrosis.

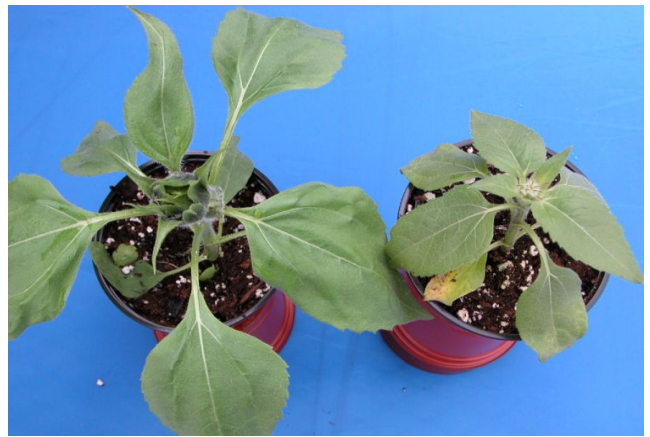

Figure 9. Phosphorus deficiency (right) compared to a healthy sunflower plant (left). Deficiency symptoms included stunted plants with dark green lower leaves and dead patches on leaf margins.

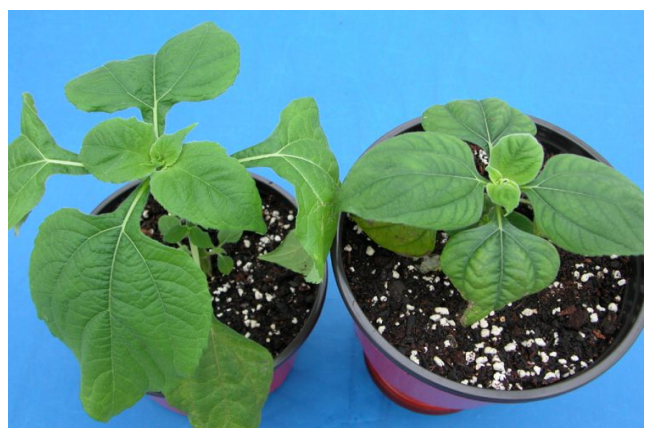

Figure 10. Potassium deficiency (right) compared to a healthy Mexican sunflower plant (left). Deficiency symptoms included wilted plants with interveinal chlorosis on all leaves.

\section{Resources}

Related EDIS extension publications:

Nitrogen deficiency in palms.

http://edis.ifas.ufl.edu/pdffiles/EP/

EP26800.pdf. 


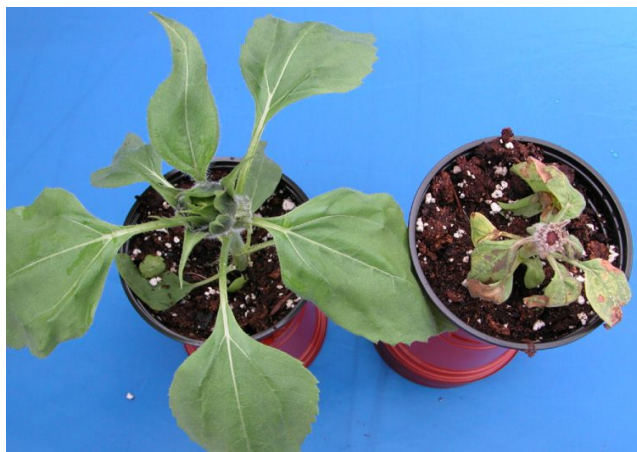

Figure 11. Calcium deficiency (right) compared to a healthy sunflower plant (left). Deficiency symptoms included dead shoots and flower bud abortion.

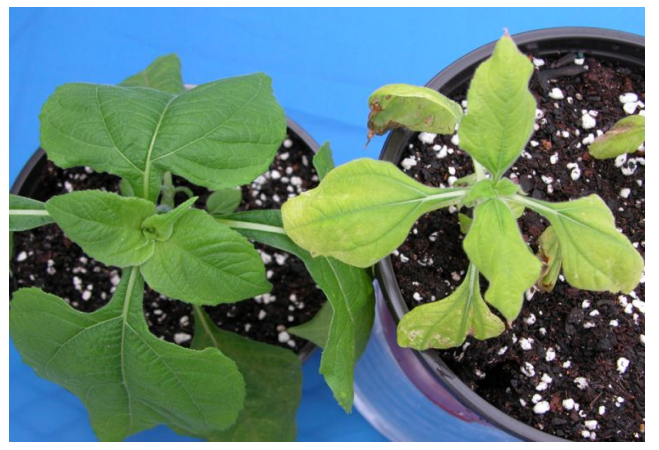

Figure 12. Magnesium deficiency (right) compared to a healthy Mexican sunflower plant (left). Deficiency symptoms included interveinal chlorosis on recently mature leaves and cupped mature leaves.

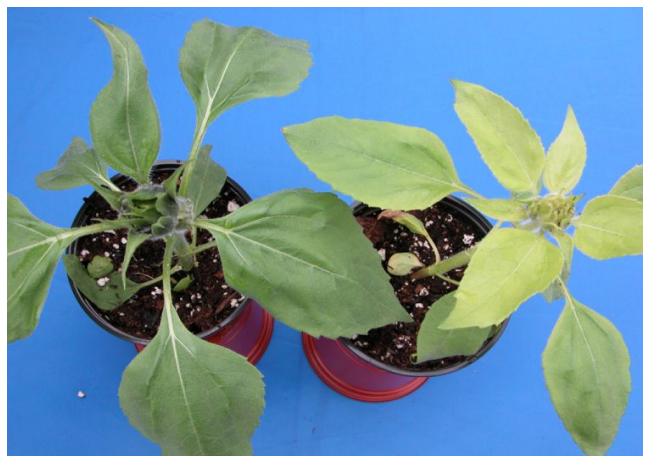

Figure 13. Sulfur deficiency (right) compared to a healthy sunflower plant (left). Deficiency symptoms included uniform light green youngest and young leaves and poor axillary shoot growth.

Nutrient deficiencies of landscape and field-grown palms in Florida.

http://edis.ifas.ufl.edu/pdffiles/EP/ EP27300.pdf.

Other grower web sites etc.

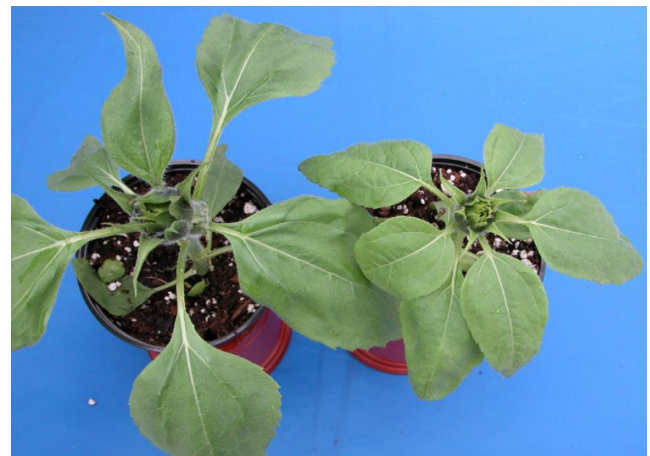

Figure 14. Boron deficiency (right) compared to a healthy sunflower plant (left). Deficiency symptoms included stunted plants with short petioles and brittle leaves.

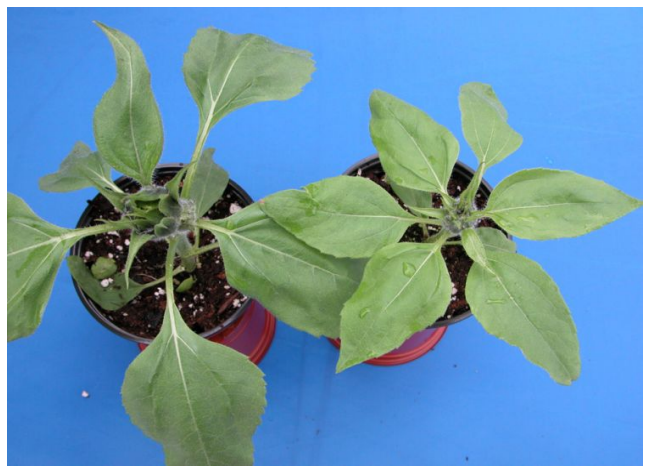

Figure 15. Copper deficiency (right) compared to a healthy sunflower plant (left). Deficiency symptoms included stunted plants with short petioles and dull green leaves.

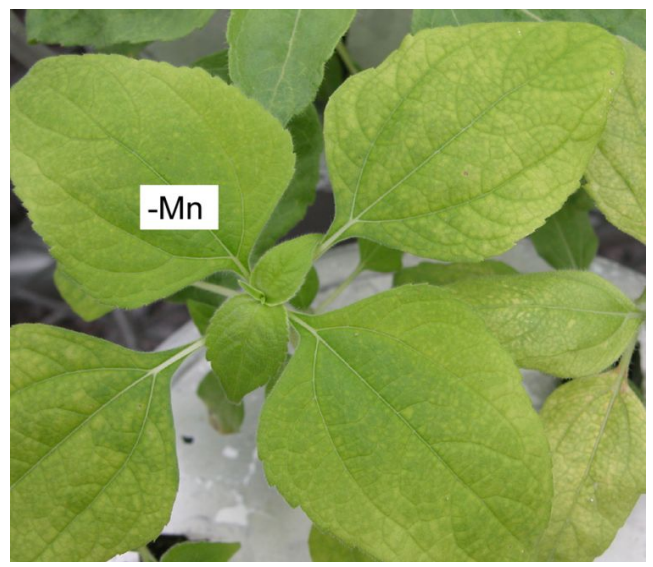

Figure 16. Manganese deficiency in Mexican sunflower. Deficiency symptoms included yellowish-green youngest leaves with mottled young leaves.

- Gibson, J.L. 2004. Nutrient deficiencies of pot sunflower 'Big Smile'. University of Florida-Milton.

- Gibson, J.L. 2004. Nutrient deficiencies of Mexican sunflower. University of Florida-Milton. 


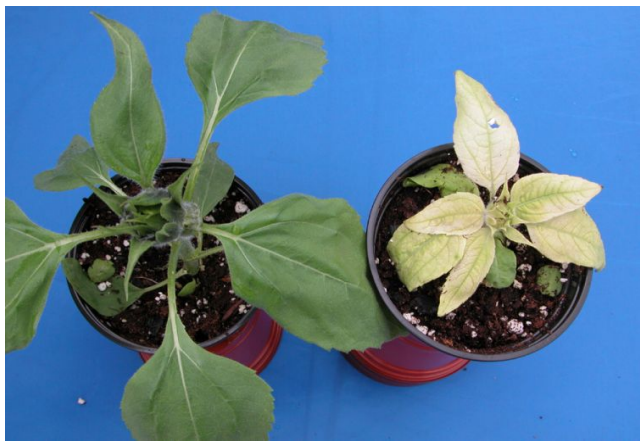

Figure 17. Iron deficiency (right) compared to a healthy sunflower plant (left). Foliar deficiency symptoms progressed from a bright green to a dull, yellowish-white color on young leaves.

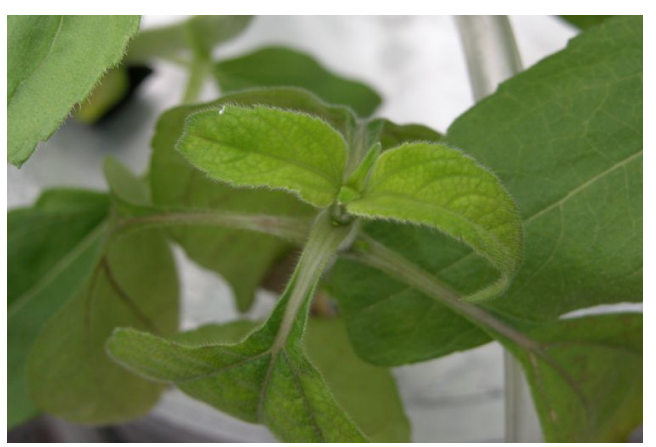

Figure 18. Zinc deficiency in Mexican sunflower. Deficiency symptoms included curled youngest leaves and thick chlorotic young leaves.

- Gibson, J.L., D. Pitchay, A. Williams, P. Nelson, and B. Whipker. 2002. Floriculture deficiency series. North Carolina State University.

http://www.ces.ncsu.edu/depts/hort/floriculture/ def.

- Gibson, J.L., P. Nelson, D. Pitchay, and B. Whipker. 2001. Identifying nutrient deficiencies of bedding plants. North Carolina State University.

http://www.ces.ncsu.edu/depts/hort/floriculture/ Florex/BP\%20ID\%20Nut\%20Def.pdf. 